\title{
The Study Of Malang Thematic Kampong As A Potential INTERNATIONAL TOURISM DESTINATION WiTH THE GENIUS LoCI CONCEPT
}

\section{KaJian Potensi Wisata InTERnaSional KaMPUng TEMATIK Kota MALANG DENGAN KonSEP GeNIUS LOCI}

\author{
Debri Haryndia Putri ${ }^{1^{*}}$, Titi Ayu Pawestri ${ }^{2}$ \\ Programme Study of D4 Graphic Design, Brawijaya University ${ }^{1}$ \\ *debriputri@ub.ac.id* \\ Programme Study of D4 Graphic Design, Brawijaya University ${ }^{2}$
}

\begin{abstract}
Thematic Kampong is one of the government's efforts to overcome settlements problem aimed to improve the quality of the environment through the area arrangement and development based on the dynamic of local uniqueness and potency. Currently, Malang has about 78 Thematic Kampongs. So, the purpose of this research is to analyze the implementation of Genius Loci concept on the Malang Thematic Kampongs. The result of this analysis could be a guideline design to develop the Thematic Kampong into international tourism destinations in Malang. Therefore, this research is using qualitative descriptive method with phenomenology approached. To analyze the readiness of potential international tourism destination on all Thematic Kampongs, this research is using quantitative methods with questionnaire technique. The result shows that the $3 G$ Kampong has succeeded in applying the concept of Genius Loci in its development and very potential to become an international tourist village.
\end{abstract}

Keywords: thematic kampong, genius loci, tourist destination

\section{PENDAHULUAN}

Kampung tematik adalah sebuah upaya menata dan mengembangkan kawasan berbasis potensi lokal yang unik dan dinamis (Ujianto, Zahro, dan Maringka, 2018). Saat ini, kampung tematik menjadi garda terdepan pembangunan pariwisata Kota Malang. Saat ini, Kota Malang telah memiliki sekitar 78 kampung yang tersebar di penjuru Kota Malang (Suryo, 2017). Akan tetapi, tidak semua kampung tematik ini memiliki keberlanjutan secara sosial, ekonomi, lingkungan dan mengangkat lokalitas sebagai nilai jual dalam bersaing secara global.

Lokalitas merupakan bagian yang tidak dapat terpisahkan dari konsep genius loci dalam keilmuan arsitektur (Winarni, 2011). Kata
"Genius" merujuk kepada karakter penanda elemen alam tertentu, sedangkan kata "Loci" berarti tempat atau lokal, sehingga kata Genius yang disandingkan dengan kata Loci menjadi bermakna keunikan lokal, potensi lokal, keautentikan suatu lokalitas tertentu (Artiningrum dkk, 2017). Menurut NorbergSchulz (1991), semua tempat di dunia ini memiliki jiwa. Konsep Genius Loci merefleksikan keunikan dari sebuah tempat, yang membedakan satu tempat dengan tempat yang lain. Genius Loci (spirit of place) dianggap menyimbolkan kekuatan "karakter" yang diwakili oleh "atmosfer" yang menjadikan suatu "ruang" yang merupakan perwujudan elemen tiga dimensi menjadi bermakna dan memberikan pengalaman ruang 
bagi penggunanya yang bergantung pada perlakuan konkret pengguna terhadap elemen ruang (Dewi, Putra dan Priautama, 2017). Selain memberikan nilai jual tersendiri yang membedakan dengan karakter destinasi pariwisata daerah lainnya, konsep ini juga dapat memberikan keberlanjutan dalam kehidupan masyarakat. Dalam mewujudkan spirit of place, terdapat 4 parameter utama yaitu:

a. Physical control (pengendalian iklim untuk keseimbangan alam)

b. Functional frame (fungsi ruang untuk kegiatan manusia)

c. Social Milleau (representasi sistem sosial sebagai satu kesatuan)

d. Cultural Symbolization (simbol budaya sebagai obyek hasil karya manusia)

Sebagai salah satu jenis perwujudakan kampung wisata, kampung tematik merupakan wujud integrasi antara atraksi, akomodasi, dan fasilitas pendukung yang disajikan dalam suatu struktur kehidupan masyarakat di mana terdapat sekelompok wisatawan yang dapat tinggal atau berdekatan dengan lingkungan tradisional tersebut untuk belajar mengenai kehidupan masyarakatnya. Berdasarkan ketiga bentuk integrasi tersebut, untuk menjadi sebuah destinasi wisata bertaraf internasional, kampung tematik harus memiliki 3 elemen desa/kampung wisata (Istoc, 2012) yaitu elemen dasar (primary elements) meliputi fasilitas budaya dan tatanan fisik lingkungan, elemen sekunder (secondary elements) yang meliputi fasilitas-fasilitas pendukung kehidupan warga dan wisatawan seperti pasar, penginapan dan lain sebagainya, serta elemen tambahan (additional elements) yang meliputi fasilitas pendukung pada sebuah kawasan wisata seperti fasilitas aksesibilitas, sarana transportasi dan parkir, dan pusat informasi untuk turis.

Selama ini keberadaan kampung-kampung tematik di Malang belum dapat menunjukkan keberlanjutan secara sosial budaya, ekonomi, serta belum mengedepankan konsep genius loci di dalam perancangannya. Keberadaan kampung tematik tersebut belum menjadi bagian keseharian dari para warga. Selain itu sebagai sebuah destinasi wisata, kampung tematik yang sekarang menjamur di Kota Malang muncul secara instan dan dipaksa untuk menjadi destinasi wisata dengan cepat dalam volume yang besar tanpa perancangan strategi pengembangan yang komprehensif dengan mempertimbangkan keberadaan tiga elemen dasar desa/kampung wisata sebagai modal bagi kampung-kampung tematik di Kota Malang menjadi destinasi wisata internasional. Kondisi-kondisi tersebut tentu sangatlah mengkhawatirkan, apabila suatu saat trend kampung tematik telah memudar dan tingkat kunjungan wisatawan mulai berkurang, maka tidak ada keberlanjutan bagi kehidupan masyarakat kampung tersebut.

\section{METODE PENELITIAN}

Penelitian ini menggunakan dua buah metode yaitu metode kualitatif dengan pendekatan secara fenomenologi dan metode kuantitatif dengan teknik kuesioner. Metode kualitatif fenomenologi digunakan peneliti untuk mendeskripsikan potensi ketiga kampung yang menjadi obyek studi yaitu Kampung 3G, Kampung Warna-warni, dan Kampung Topeng dari sisi pengaplikasian 4 parameter Genius Loci antara lain Physical control, Functional frame, Social Milleau, Cultural Symbolization sebagai manifestasi aspek keberlanjutan bagi kehidupan masyarakat kampung. Sedangkan metode kuantitatif melalui kuesioner yang dibagikan kepada 35 responden yang digunakan peneliti untuk melakukan analisa 3 elemen dasar yang wajib dimiliki kampung wisata bertaraf internasional yang meliputi:

a. Primary elements, meliputi fasilitas budaya dan tatanan fisik lingkungan

b. Secondary element yang meliputi fasilitasfasilitas pendukung kehidupan warga dan wisatawan seperti pasar, penginapan dan lain sebagainya

c. Additional elements yang meliputi fasilitas pendukung pada sebuah kawasan wisata seperti fasilitas aksesibilitas, sarana transportasi dan parkir, dan pusat informasi untuk turis.

\section{HASIL DAN PEMBAHASAN}

\subsection{Gambaran Umum Kampung 3G}

Kampung Glintung Go Green (3G) dahulu merupakan kampung kumuh dengan berbagai masalah sosial dan lingkungan. Secara geografis, kampung ini terletak di Jl. S. 
Parman, RW 23, Kelurahan Purwantoro, Kecamatan Blimbing, Kota Malang, Jawa Timur. Sebelum kampung ini berdiri, kawasan Glintung merupakan daerah resapan air yang berfungsi dengan sangat baik (Utami, 2017). Seiring kebutuhan masyarakat akan tempat bermukim, kampung $3 \mathrm{G}$ menjadi padat dan menimbulkan banyak permasalahan antara lain:
a. Banjir
b. Kekeringan
c. Infrastruktur pemukiman yang buruk
d. Angka kriminalitas yang tinggi
e. Tingkat kesehatan masyarakat yang rendah
f. Tingkat perekonomian masyarakat yang rendah

Melihat kondisi tersebut, pada tahun 2012, Ketua RW 23, Ir. H. Bambang Irianto, mencoba mengubah keadaan kampong bersama masyarakat. Inisiatifnya adalah merubah wajah kampong yang diwujudkan dalam sebuah gerakan sosial berbasis penghijauan bernama Glintung Go Green (3G). Pada tahun 2013, gerakan ini berbuah hasil, masyarakat mulai sadar akan pentingnya lingkungan permukiman yang sehat dikarenakan kondisi Kampung 3G yang semakin membaik dan bebas dari banjir. Kampung 3G mendapatkan banyak penghargaan sebagai kampong tematik berbasis penghijauan dan konservasi air. Puncaknya adalah, terpilihnya Kota Malang melalui Gerakan Menabung Air - Kampung 3G sebagai 15 shortlisted city for Guangzhou International Award of Urban Innovation.

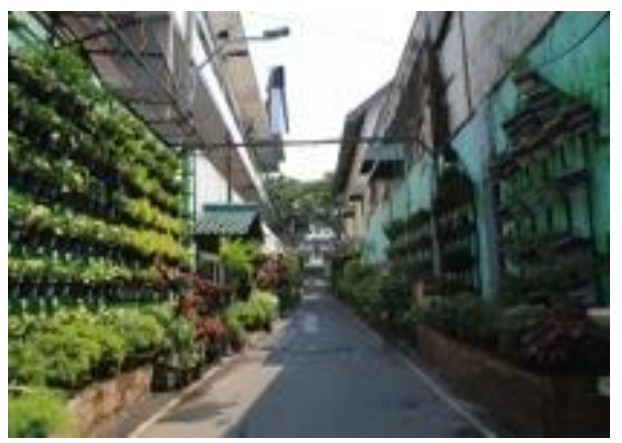

Gambar 1. Area Masuk Kampung 3G

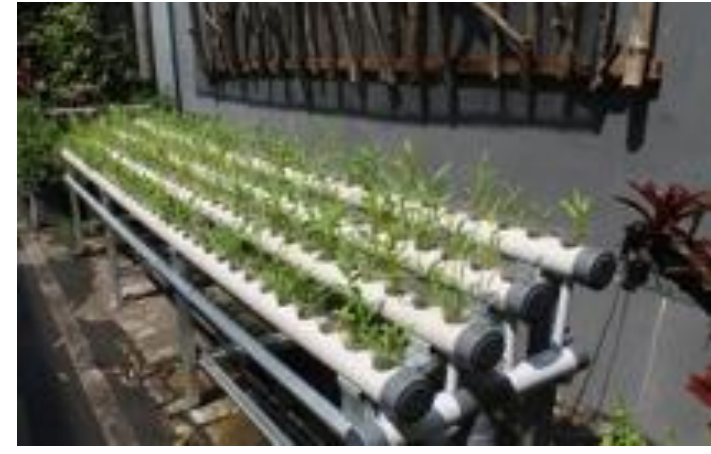

Gambar 2. Deretan Tanaman Hidroponik Penghias Kampung

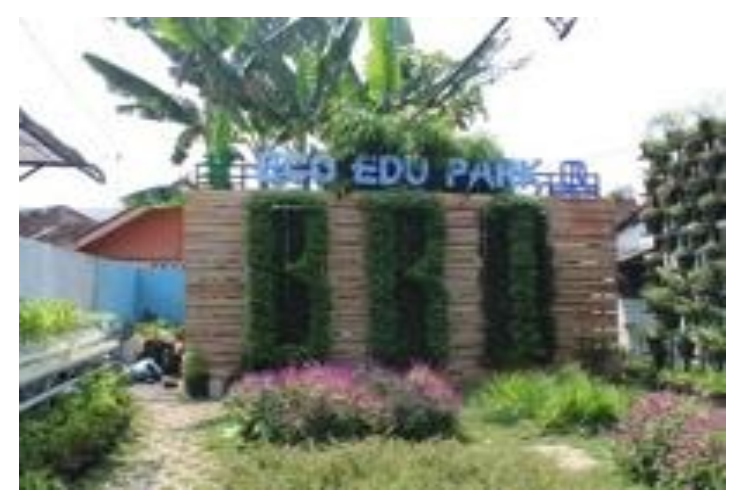

Gambar 3. Area Terbuka Hijau di Lingkungan Kampung 3G

\subsection{Gambaran Umum Kampung Warna- Warni}

Kampung Warna-Warni Jodipan merupakan salah satu kampung tematik yang berada tepat ditengah Kota Malang. Lokasinya yang berada di Jalan Gatot Subroto atau tepat di bawah jembatan Embong Brantas. Pada awalnya, kampung merupakan kampung kumuh yang berdiri dibantaran Sungai Brantas. Sebelumnya, masyarakat di kampung Jodipan ini memiliki kesadaran yang rendah akan menjaga lingkungangannya yang menyebabkan beragam masalah yang timbul (Aeni, 2017) antara lain:

a. Sampah

b. Bau tidak sedap dan menyengat

c. Infrastruktur yang tidak terawat dan rusak

d. Tingginya angka kriminalitas yang dikarenakan rendahnya tingkat ekonomi masyarakat,

e. Tingkat kesehatan yang rendah dan lingkungan yang tidak sehat. 
Selain kondisi lingkungan yang kumuh dan tidak sehat, lokasi dari kampung ini juga melanggar Peraturan Daerah ( Perda ) Kota Malang Nomor 1 Tahun 2012 tentang Bangunan Gedung. Dalam aturan tersebut, menjelaskan bangunan dan garis sempadan untuk keamanan, keindahan dan penataan kota.

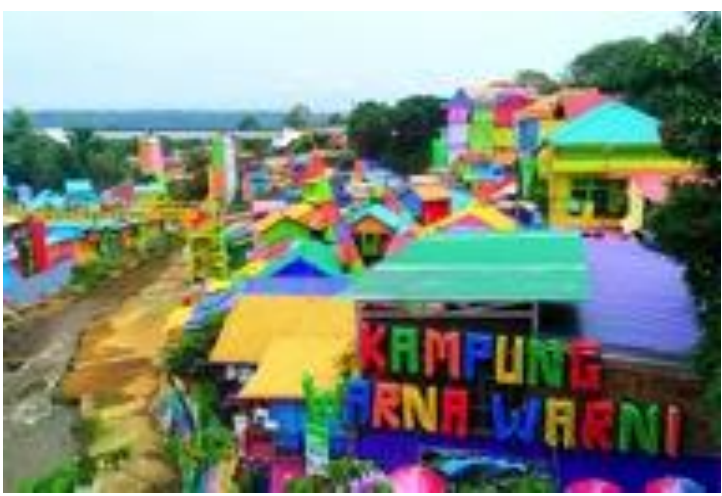

Gambar 4 Visualisasi Kampung Warna-Warni

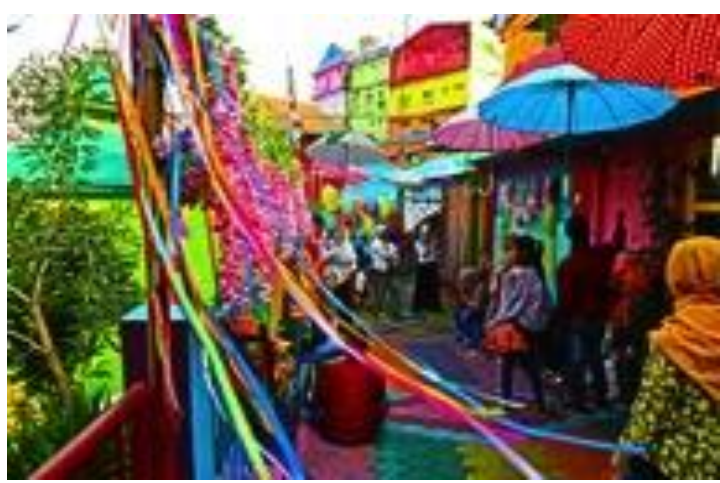

Gambar 5. Visualisasi Koridor Jalan Kampung Warna-Warni

Ide awal perbaikkan Kampung Jodipan menjadi kampung Warna-Warni di Kota Malang ini digagas oleh sekelompok mahasiswa yang berupaya untuk merubah kampung yang awalnya terlihat kotor menjadi lebih indah dan memiliki nilai jual visual. Cara yang dipilih yaitu dengan membuat kampung tematik dengan konsep berwarna-warni seperti Desa Favela di Rio De Janeiro, Brazil. Upaya para mahasiswa ini dinilai cukup berhasil, kampung yang awalnya akan digusur oleh Pemerintah Kota Malang ini, diresmikan dan ditetapkan sebagai salah satu tujuan wisata baru di Kota Malang.

\subsection{Gambaran Umum Kampung Topeng}

Kampung Topeng ini merupakan sebuah kampung yang awalnya merupakan lahan kosong yang dibuat menjadi pemukiman untuk anak jalanan. Pembuatan Kampung ini sepenuhnya dilakukan oleh Dinas Sosial Kota Malang. Kampung wisata tematik ini merupakan salah satu kampung tematik yang menggunakan konsep pelestarian budaya khas Kota Malang, yaitu Topeng Malangan.

Kampung Topeng ini tepatnya berada di Desa Menanti yang berjarak sekitar $15 \mathrm{~km}$ dari pusat Kota Malang. Kampung Topeng merupakan salah satu upaya pengentasan kemiskinan yang dilakukan oleh Kementerian Sosial Republik Indonesia melalui program "Desaku Menanti" dari Direktorat Jenderal Rehabilitasi Sosial, Kementerian Sosial Republik Indonesia yang bertujuan untuk merehabilitasi anak jalanan, gelandangan, dan pengemis. Kampung Topeng merupakan wadah memukimkan para Anjal dan Gepeng agar dapat menjadi warga yang bermartabat dengan diberikan tempat yang layak serta didampingi dalam melakukan proses bermukim dengan aktivitas yang dapat melakukan peningkatan taraf hidup serta memajukan pendapatannya (Subadyo, 2018). Proses pemukiman mereka dilakukan dengan cara persuasif, melalui seleksi ini agar para Anjal dan Gepeng berkomitmen untuk berbenah diri dan tidak kembali mengemis dijalan. Tema Topeng Malangan dipilih dengan alasan bahwa salah satu ikon dan identitas kota Malang yang bisa dengan mudah diapresiasi oleh masyarakat adalah keberadaan kesenian dan budaya topeng malangan. Tema ini cukup potensial untuk ditingkatkan agar Kampung Topeng dapat menjadi sebuah destinasi wisata baru di Kota Malang. 


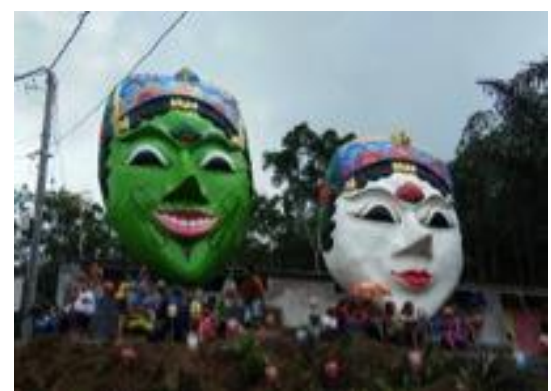

Gambar 6. Visualisasi Area Pintu Masuk Kampung Topeng

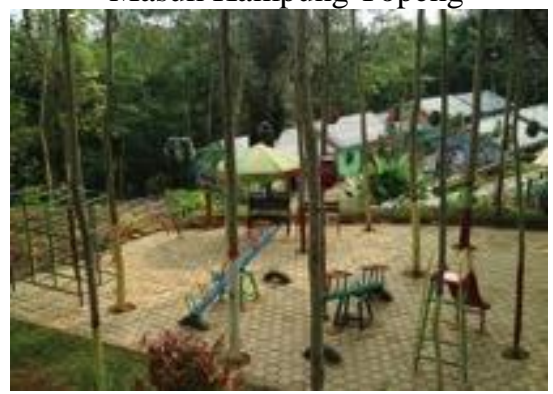

Gambar 7. Area Bermain pada Kampung Topeng

\subsection{Analisa Penerapan Konsep Genius Loci dan Standar Kampung Wisata Internasional pada Kampung 3G}

Pada Kampung 3G, kontrol fisik yang paling menonjol adalah gerakan penghijauan dan konservasi air. Gerakan penghijauan diperuntukkan untuk mengurangi ancaman banjir, mengontrol kebutuhan masyarakat akan udara bersih, menjaga kelembaban udara, melindungi pemukiman dari sengatan matahari berlebih, menurunkan temperatur lingkungan dan penanganan kebisingan akibat dekatnya jarak pemukiman dengan jalan raya dan rel kereta api. Secara visual, gerakan ini tampak sangat jelas pada keberadaan tanaman seperti sayur mayur, hidroponik, toga, dan bunga pada area pintu masuk kampung, dinding batas kampung sepanjang jalan utama, area publik seperti taman dan area depan rumah warga. Kampung 3G muncul sebagai sebuah jawaban dari permasalahan lingkungan yang ada, visualisasi kampung yang estetis merupakan nilai tambah dari keberadaan area penghijauan tersebut. Di saat kampong tematik lain lebih menawarkan keatraktifan visualnya, kampung ini telah menerapkan konsep Genius Loci dengan mengangkat penghijauan dan konservasi air sebagai spirit of place dan menemukan fungsi utamanya dalam merevitalisasi lingkungannya sehingga Kampung 3G memiliki nilai keberlanjutan yang tinggi.

Kampung 3G telah mampu memenuhi aspek functional frame dari konsep genius loci dimana kampung ini telah mewadahi kebutuhan dan aktivitas warga akan pemukiman yang sehat. Sebagai sebuah destinasi wisata, kampung $3 \mathrm{G}$ juga telah mewadahi aktivitas berswafoto pengunjung melalui peletakkan area-area foto serta penataan area-area penghijauan secara estetis. Namun, perubahan area privat menjadi area publik mengakibatkan belum terwadahinya beberapa aktvitas pengunjung antara lain loket, area parkir, rest area, guest house serta pertokoan yang menjual merchandise kampung yang khas.

Aspek Social milleu tampak pada hubungan sosial yang terjadi pada kampung tersebut telah terjalin dengan sangat baik. Ketua RW sebagai koordinator warga telah melakukan fungsinya, hubungan sosial warga yang diwujudkan dalam gotong royong membentuk ruang-ruang terbuka hijau menjadi spirit of place Kampung 3G. Warga yang proaktif merupakan salah satu aspek social milleu yang mendukung keberlanjutan sebuah kampung tematik.

Aspek cultural symbolization pada Kampung $3 \mathrm{G}$ terbentuk dari area-area penghijauan dan konservasi air pada Kampung $3 \mathrm{G}$ yang menyampaikan pesan budaya gotong royong pada masyarakat Indonesia. Perubahan peran Kampung 3G menjadi sebuah destinasi wisata baru yang memiliki fasilitas spot foto bagi pengunjung sebagai bagian dari sebuah kampung tematik merupakan simbol budaya millenial.

Kampung 3G telah siap menjadi kampung wisata internasional berdasarkan Standar Kampung Wisata Internasional (Istoc, 2012) yang terdiri dari 3 elemen seperti primary elements (keberadaan galeri, bengkel, karakteristik tematik, visualisasi yang menarik, area tematik dan area hijau), secondary elements (keberadaan pasar, kios, restoran, dan hotel / penginapan), serta additional elements (keberadaan akses ke lokasi, transportasi umum, area parkir dan signage). Untuk menilai penerapan setiap 
elemen, peneliti menggunakan metode kuantitatif dengan teknik kuesioner yang diberikan kepada 35 pengunjung. Hasil penelitian menunjukkan bahwa kampung $3 \mathrm{G}$ telah mampu memenuhi seluruh elemen dalam primary elements pada standar kampung wisata internasional. Sebanyak 19 pengunjung $(54,3 \%)$ menyatakan bahwa Kampung 3G telah memiliki galeri / museum yang berfungsi sebagai tempat untuk menampilkan fitur khas desa. Selain itu, total 20 pengunjung $(31,4 \%)$ menyatakan bahwa kampung tematik ini telah memiliki fasilitas workshop sebagai platform untuk memperkenalkan budaya desa. Selanjutnya, 23 pengunjung $(65,7 \%)$ menyatakan bahwa karakteristik yang dimiliki oleh kampung 3G dapat menjadi bahan pembelajaran dan menambah pengetahuan. Kemudian, 26 pengunjung (74,3\%) menyatakan bahwa visualisasi area-area penghijauan pada kampung menjadi adalah daya tarik utama kampung 3G. 21 orang $(54,3 \%)$ menganggap bahwa desa tersebut memiliki area tematik berupa area penghijauan serta area konservasi air yang menjadi ciri khas serta unique selling point Kampung 3G. Dan pada pertanyaan elemen primer yang terakhir, hasil jawaban 35 orang responden (100\%) menunjukkan bahwa kampung tematik $3 \mathrm{G}$ memiliki area hijau / taman sebagai area penghijauan desa dan daya tarik utama dari Desa Tematik. Dari penjelasan di atas, dapat dilihat, bahwa sebagai kampung teamtik, Kampung 3G telah mampu memenuhi enam elemen dalam elemen primer dari standar kampung wisata internasional.

Dari hasil kuesioner secondary elemenst, dapat dilihat bahwa Kampung 3G hanya mampu memenuhi dua dari empat aspek standar yaitu ketersediaan kios dan restaurant pada area kampung. Dari hasil analisa kuesioner dapat dilihat bahwa keberadaan pasar/tempat perbelanjaan pada area kampung dijawab oleh 7 pengunjung (20\%). 21 pengunjung $(60 \%)$ menyatakan pada kampung ini telah tersedia toko/kios lokal. Kemudian, 18 pengunjung $(51,4 \%)$ menyatakan akan ketersediaan area makan/restoran di area kampung. Terakhir, hanya 8 orang $(22,9 \%)$ menyatakan jika kampung memiliki fasilitas hotel/penginapan. Dari hasil tersebut dapat diketahui, jika kampung tematik $3 \mathrm{G}$ hanya mampu memenuhi
2 dari 4 unsur elemen sekunder kampung wisata Internasional. Hal ini menunjukkan bahwa Kampung 3G belum mampu memenuhi aspek sekunder kampung wisata internasional, uantuk itu kedepannya, pengembangan kampung 3G sebagai destinasi wisata internasional sebaiknya diarahkan untuk pemenuhan fasilitas-fasilitas elemen sekunder tersebut.

Hasil kuesioner additional elements menunjukkan bahwa Kampung 3G telah mampu memenuhi semua elemen tambahan standar kampung wisata internasional. Untuk aspek unsur akses/jalan, 26 orang pengunjung di kampung $3 \mathrm{G}(74,9 \%)$ menyatakan jalanan mudah dilalui/ditemukan. Lalu 19 orang $(54,9 \%)$ orang menyatakan jika dapat ditemukan transportasi umum di sekitaran kampung tematik. Untuk area parkir sendiri, 20 orang $(57,1 \%)$ menyatakan akan ketersediaannya area untuk parkir bagi kendaraan roda 2 ataupun 4 . Terakhir, 28 orang $(31,4 \%)$ menyatakan jika signage/papan petunjuk di kampung tematik dapat lebih memudahkan pengunjung. Hasil dari diagram diatas, dapat menunjukkan jika Kampung 3G mampu memenuhi semua unsur pembentuk additional element agar kampung 3G dapat menjadi kampung wisata internasional.

Dari penjelasan di atas, dapat disimpulkan bahwa Kampung 3G telah berhasil memenuhi 2 dari 3 elemen standar kampung wisata seperti pada gambar 4. Hal ini menunjukkan bahwa Kampung Tematik 3G telah didesain dengan menggunakan konsep genius loci dan telah siap untuk dikembangkan menjadi sebuah destinasi wisata internasional. 


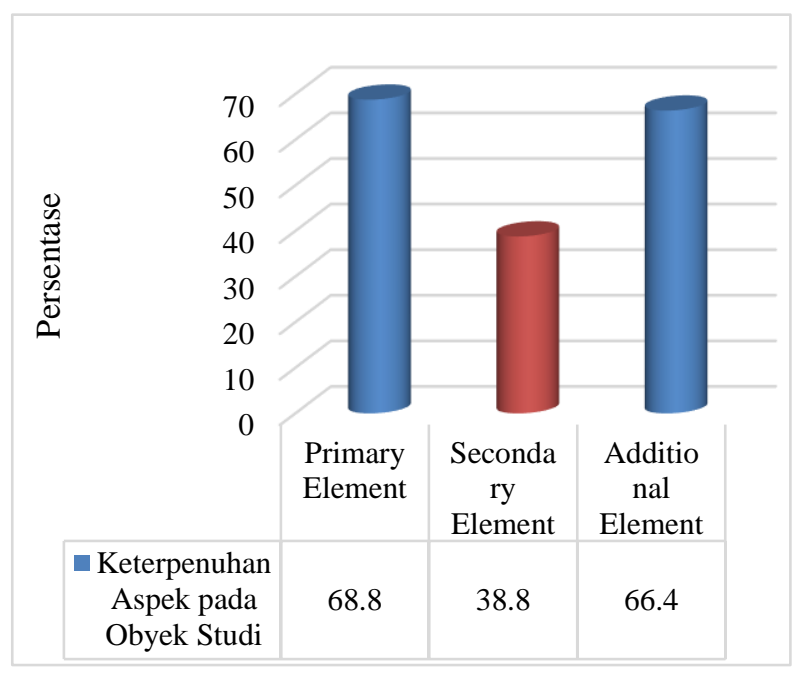

Gambar 8. Hasil Kesimpulan Kuisioner Standar Kampung Wisata Internasional pada Kampung 3G

\subsection{Analisa Penerapan Konsep Genius Loci dan Standar Kampung Wisata Internasional pada Kampung Warna- Warni}

Keberadaan Kampung Jodipan pada dasarnya melanggar Undang-undang Nomor 1 tahun 2011 pasal 140 tentang Perumahan dan kawasan permukiman, dimana "Setiap orang dilarang membangun, perumahan, dan/atau permukiman di tempat yang berpotensi dapat menimbulkan bahaya bagi barang ataupun orang." yang dimaksud dengan "tempat yang berpotensi dapat menimbulkan bahaya" antara lain, sempadan rel kereta api, bawah jembatan, daerah Saluran Udara Tegangan Ekstra Tinggi (SUTET), Daerah Sempadan Sungai (DSS), daerah rawan bencana, dan daerah kawasan khusus seperti kawasan militer. Dari pasal tersebut secara aspek physical control, kampung Warna-Warni tidak berhasil menerapkan kontrol fisik terhadap lingkungannya. Berbagai permasalahan lingkungan banyak ditemui pada Kampung Warna-Warni antara lain gangguan akustik akibat dekatnya jarak lokasi pemukiman dengan rel kreta api dan jalan raya, polusi udara dalam bentuk asap maupun debu akibat banyaknya kendaraan bermotor yang lalu lalang, serta kondisi saluran pembuangan yang kurang lancar atau terhambat yang menjadi penyebab timbulnya bau yang tidak sedap pada lingkungan kampung. Namun sebenarnya, masyarakat dan pemerintah telah melakukan beberapa kontrol fisik pada lingkungannya yang cukup mempengaruhi psikologi pengunjung antara lain merancang area peneduh berupa barisan payung yang digantung berjajar, membangun jebatan yang menghubungkan dua buah sisi kampung yang terpisah oleh sungai sehingga memudahkan aksesibilitas warga dan pengunjung, serta penempatan tanaman artificial untuk menambah estetika kampung.

Secara functional frame, kampung tematik ini diciptakan guna memenuhi kebutuhan masyarakat milenial saat ini, yaitu untuk berfoto dan mengabadikan momen. Kampung Jodipan yang awalnya merupakan pemukiman yang bersifat privat beralih fungsi menjadi publik ketika mulai dijadikan tujuan wisata. Dinding dan atap rumah dicat warna-warni, area teras dan ruang tamu rumah warga berubah menjadi toko, area jalan warga dihias dengan berbagai pernik dekorasi seperti payung yang berfungsi sebagai peneduh serta bunga-bunga artificial sebagai penambah nilai estetika, dan beberapa area terbuka pemukiman berubah fungsi menjadi area peristirahatan bagi para pengunjung. Genius Loci dari kampung ini terletak pada perubahan visualisasi kampung akibat perubahan status kampung menjadi tempat wisata, namun perubahan ini tidak diikuti dengan perubahan pola kebiasaan atau kegiatan warganya, sehingga kedepannya perlu adanya edukasi bagi terkait perubahan perilaku yang dapat mendukung fungsi Kampung Jodipan sebagai salah satu tujuan wisata.

Aspek Social Millieu pada kampung Jodipan dapat dilihat pada hubungan antara penduduk dengan penduduk, penduduk dengan pengunjung dan juga hubungan antara penduduk dengan Pemerintah. Aspek Social Milleu pada kampung Jodipan ini didominasi oleh sistem sosial yang dibentuk oleh Pemerintah Kota Malang dengan warga. Kampung yang pada awalnya hendak digusur karena menyalahai Peraturan Daerah tentang mendirikan bangunan ini, kini mendapat perhatian dan perlindungan khusus dari Pemerintahan Kota Malang. Selain itu terjalin pula hubungan antara warga dengan pengunjung yang mampu menghasilkan perubahan positif antara lain peningkatan 
perekonomian melalui perubahan profesi warganya menjadi pedagang. Kesadaran warga akan perubahan status kampung juga membentuk sistem sosial yang baik di antara warga yang membentuk perasaan memiliki pada kampung yang berdampak pada kemauan semua warga untuk bergotongroyong dalam merevitalisasi kampung.

Kampung ini dirancang untuk memenuhi kebutuhan masyarakat modern unuk berswafoto yang merupakan murni wisata yang ditawarkan oleh Kampung Jodipan. Secara cultural symbolization keunggulan visual di Kampung Jodipan ini tidak diimbangi dengan inovasi lain yang dapat meningkatkan sustainabilitas kampung.

Berdasarkan analisa dan evaluasi penerapan standar kampung wisata internasional, Kampung Warna-warni belum cukup siap untuk menjadi sebuah destinasi wisata internasional. Standar Kampung Wisata Internasional (Istoc, 2012) terdiri dari 3 elemen seperti elemen primer (keberadaan galeri, bengkel, karakteristik tematik, visualisasi yang menarik, area tematik dan area hijau), elemen sekunder (keberadaan pasar, kios, restoran, dan hotel / penginapan), serta elemen tambahan (keberadaan akses ke lokasi, transportasi umum, area parkir dan signage). Untuk menilai penerapan setiap elemen, peneliti menggunakan metode kuantitatif dengan teknik kuesioner yang diberikan kepada 35 pengunjung.

Standar elemen primer kampung wisata internasional terdiri atas 6 unsur. Dari diagram 5 dapat diketahui jika 13 orang pengunjung $(37,1 \%)$ menyatakan jika Kampung WarnaWarni Jodipan memiliki gallery/museum yang dijadikan tempat untuk menampilkan ciri khas dari kampung itu. Selaian itu hanya 11 pengunjung $(31,4 \%)$ menyatakan jika kampung tematik memiliki workshop khusus sebagai tempat untuk memperkenalkan budaya ciri khas kampung. Selanjutnya, 13 pengunjung $(37,1 \%)$ menyatakan jika ciri khas yang dimiliki oleh kampung tematik dapat menjadi bahan pembelajaran dan menambah ilmu. Kemudian 30 pengunjung $(85,7 \%)$ visualisasi dari kampung merupahan hal yang menarik dari kampung tematik tersebut. 16 orang $(45,7 \%)$ menganggap jika kampung memiliki area khusus yang merupakan ciri khas kampung tematik. Terakhir, hanya 10 orang pengunjung $(28,6 \%)$ menunjukkan jika kampung memeiliki area hijau/taman sebagai area penghijau kampung. Dari penjelasan dapat diketahui, jika kampung tematik hanya mampu memenuhi 1 dari 6 unsur, yaitu terpenuhinya unsur keunikan atau kelebihan visual.

Standar secondary element sendiri terbagi menjadi 4 unsur yaitu pasar/tempat perbelanjaan, toko/kios lokal, restoran/tempat makan dan hotel/penginapan. Untuk pasar/tempat perbelanjaan dari diagram 6 dapat diketahui bahwa 10 pengunjung $(28,5 \%)$ menyatakan akan tersedianya unsur pasar dalam kampung. Kemudian 31 pengunjung $(88,5 \%)$ menyatakan tersedianya toko/kios lokal berada di dalam kampung tematik. Lalu juga 21 pengunjung $(60 \%)$ menyatakan akan ketersediaan area makan/restoran di area kampung. Terakhir, hanya 5 orang $(14,2 \%)$ menyatakan jika kampung memiliki fasilitas hotel/penginapan di kampung tematik tersebut. Dari hasil tersebut mampu dikatakan, jika kampung tematik Warna-Warni Jodipan mampu memenuhi 2 dari 4 unsur secondary element kampung wisata Internasional. Terwujud dengan banyaknya pengunjung yang menyatakan adanya fasilitas akan toko/kios lokal dan tempat makan di kampung tematik tersebut.

Elemen selanjutnya merupakan additional element yang terbagi menjadi 4 unsur, yaitu unsur akses/jalan menuju lokasi, transportasi umum menuju/sekitar kampung tematik, area parkir pengunjung dan signage atau papan penunjuk. Pada diagram 7 dapat dilihat bahwa untuk unsur akses/jalan, 25 orang $(71,4 \%)$ menyatakan jalanan mudah dilalui/ditemukan. Lalu 21 orang $(60 \%)$ orang menyatakan jika dapat ditemukan transportasi umum untuk menuju atau melalui kampung tematik. Untuk area parkir sendiri, 22 orang $(62,9 \%)$ menyatakan akan ketersediaannya lahan. Terakhir, 11 orang $(31,4 \%)$ menyatakan jika signage/apan petunjuk di area kampung tematik cukup membantu pengunjung. Pemaparan diatas dapat menunjukan terpenuhinya 3 unsur dari 4 unsur additional element. Pada kampung Warna-Warni Jodipan dapat diketahui akan kurangnya Signage. 
Dari hasil analisa kuesioner seperti yang tampak pada gambar 5, dapat disimpulkan jika kampung Warna-Warni belum dapat memenuhi standar elemen untuk menjadi kampung wisata internasional. hanya mampu memenuhi 1 dari 3 standar kampung wisata internasional yaitu additional elements, Oleh karena itu diperlukan adanya inovasi demi perkembangan dan kemajuan kampung wisata tematik itu sendiri.

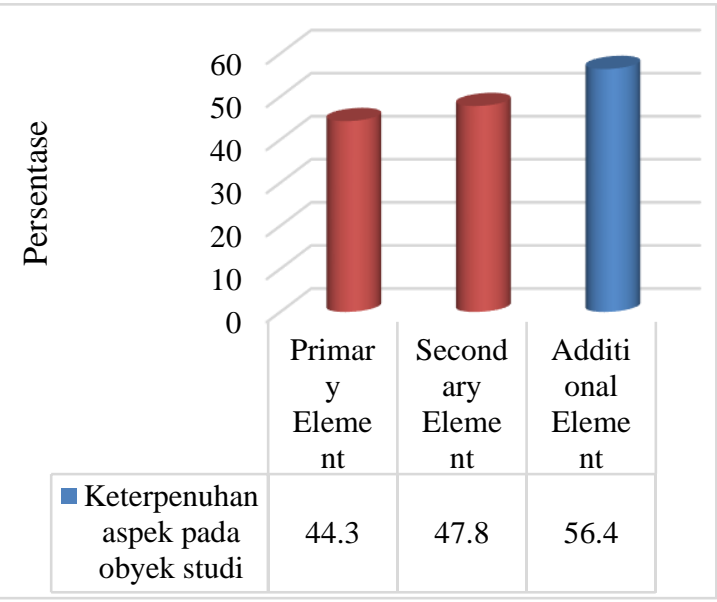

Gambar 9. Hasil Kesimpulan Kuisioner Standar Kampung Wisata Internasional pada Kampung Warna-Warni

\subsection{Analisa Penerapan Konsep Genius Loci dan Standar Kampung Wisata Internasional pada Kampung Topeng}

Aspek Physical Control dari kampung Topeng merupakan salah satu daya tarik kampung. Kampung Topeng dibangun tanpa merusak alam, kondisi area -area permukiman dirancang mengikuti kontur tanah, keberadaan area kampung yang jauh dari kota, sehingga pemukiman tidak banyak mengalami gangguan yang bersifat alam seperti cahaya, cuaca, akustik, debu, dan asap. Hal tersebut didukung dengan penataan vegetasi yang di area pemukiman yang secara keseluruhan mampu mempengaruhi psikologis pengunjung. Pengunjung akan merasa fresh dan segar ketika melihat banyaknya warna hijau disekeliling area kampung.

Secara aspek functional frame, kampung ini telah dikondisikan terbagi atas zona wisata bagi pengunjung dan zona tempat tinggal bagi warganya. secara baik Hal ini disebabkan kampung ini merupakan kampung buatan yang terbentuk karena peran Dinas Sosial Kota Malang, sehingga pembagian-pembagian area kampung yang sifatnya publik (area bermain dan spot foto) serta area privat (rumah warga) sudah cukup baik.

Aspek Sosial Milleu pada Kampung Topeng tidak terbentuk secara baik karena penghuninya merupakan anak jalanan, gelandangan dan pengemis yang awalnya tidak memiliki tempat tinggal. Penduduk Kampung Topeng berasal dari banyak tempat dan tidak memiliki kedekatan secara batin dan emosional, hal ini menyebabkan kurangnya rasa saling memiliki satu sama lain antara penduduk satu dengan penduduk lain. Hubungan antar warga kampung juga tidak terlalu erat dan tidak menghasilkan kesinergian yang berpotensi menjadi menjadi spirit of place dari kampung tersebut.

Aspek Cultural Symbolization sangat tampak terlihat pada visualisasi budaya Topeng Malangan yang mendominasi wajah kampung. Kampung ini dirancang memiliki konsep wisata edukatif melalui pengenalan budaya Indonesia khususnya Topeng Malangan yang merupakan budaya khas Malang sebagai salah satu wujud upaya pelestarian budaya. Pada aspek ini, kampung Topeng sangat dimungkinkan untuk berkembang namun karena semua penduduk adalah pendatang, penduduk kurang aktif dalam upaya pengembangan kampung. Konsep kampung yang upaya pengembangannya berpusat pada Dinas Sosial Kota Malang ini ditakutkan tidak dapat memberikan keberlanjutan bagi kehidupan masyarakat kampung tersebut.

Berdasarkan analisa dan evaluasi penerapan standar kampung wisata internasional, Kampung Warna-warni belum cukup siap untuk menjadi sebuah destinasi wisata internasional. Standar Kampung Wisata Internasional (Istoc, 2012) terdiri dari 3 elemen seperti primary elements (keberadaan galeri, bengkel, karakteristik tematik, visualisasi yang menarik, area tematik dan area hijau), secondary elements (keberadaan pasar, kios, restoran, dan hotel / penginapan), serta additional elements (keberadaan akses ke lokasi, transportasi umum, area parkir dan signage). Untuk menilai penerapan setiap 
elemen, peneliti menggunakan metode kuantitatif dengan teknik kuesioner yang diberikan kepada 35 pengunjung.

Kampung Topeng telah berhasil memenuhi standar kampung wisata internasional pada aspek primary elements sebab 4 dari 6 unsur primary elements telah hadir pada area kampung tematik ini meliputi tersedianya fasilitas gallery/museum, tersedianya workshop budaya, keunggulan ciri khas yang dijunjung dan area hijau/taman di kampung. 24 orang pengunjung $(68,6 \%)$ menyatakan jika Kampung Tematik Topeng, Desa Menanti memiliki gallery/museum yang dijadikan tempat untuk menampilkan ciri khas dari kampung itu. Juga 23 pengunjung $(65,7 \%)$ menyatakan jika kampung tematik memiliki workshop khusus sebagai tempat untuk memperkenalkan budaya ciri khas kampung. Selain itu 32 pengunjung $(91,4 \%)$ menyatakan jika ciri khas yang dimiliki olrh kampung tematik dapat menjadi bahan pembelajaran dan menambah ilmu. Kemudian 13 pengunjung $(37,1 \%)$ menyatakan jika kampung tematik cukup menarik dalam hal visualisasi kampung sendiri. 16 orang $(45,7 \%)$ menganggap jika kampung memiliki area khusus yang merupakan sebagai ciri khas kampung tematik. Terakhir, 32 orang pengunjung $(91,4 \%)$ menyatakan jika kampung memiliki area hijau/taman sebagai area penghijauan kampung.

Standar secondary element dibagi lagi menjadi 4 aspek yaitu pasar/tempat perbelanjaan, toko/kios lokal, restoran/tempat makan dan hotel/penginapan. Dari hasil evaluasi kuesioner dapat dilihat bahwa pasar/tempat perbelanjaan, 5 pengunjung $(14,3 \%)$ menyatakan akan tersedianya unsur pasar dalam kampung. Kemudian 22 pengunjung $(62,9 \%)$ menyatakan tersedianya toko/kios lokal berada di dalam kampung tematik. Lalu juga 22 pengunjung $(62,9 \%)$ menyatakan akan ketersediaan area makan/restoran di area kampung. Terakhir, hanya 11 orang $(31,4 \%)$ menyatakan bahwa kampung memiliki fasilitas hotel/penginapan di kampung tematik tersebut. Dari hasil tersebut dapat disimpulkan, jika kampung tematik Kampung Topeng, Desa Menanti mampu memenuhi 2 dari 4 unsur secondary element kampung wisata
Internasional, yaitu pada unsur keberadaan fasilitas toko/kios lokal dan area makan.

Elemen yang terakhir merupakan additional element yang dibagi menjadi 4 unsur, yaitu unsur akses/jalan menuju lokasi, transportasi umum menuju/sekitar kampung tematik, area parkir pengunjung dan signage atau papan penunjuk. Pada unsur akses/jalan, 9 orang $(25,7 \%)$ menyatakan jalanan mudah dilalui/ditemukan. Lalu 5 orang $(14,3 \%)$ orang menyatakan jika dapat ditemukan transportasi umum untuk menuju atau melalui kampung tematik. Untuk area parkir sendiri, 22 orang $(62,9 \%)$ menyatakan akan ketersediaannya lahan. Terakhir, 23 orang $(65,8 \%)$ menyatakan jika signage/apan petunjuk di area kampung tematik cukup membantu pengunjung.

Dari hasil analisa di atas, pada gambar 6, dapat disimpulkan bahwa Kampung Topeng belum dapat memenuhi standar kampung wisata internasional. Oleh karena itu perlu dilakukan perbaikan maupun inovasi dari sisi fasilitas untuk meningkatkan potensi wisata kampung tematik Topeng agar dapat memberikan aspek keberlanjutan bagi warganya.

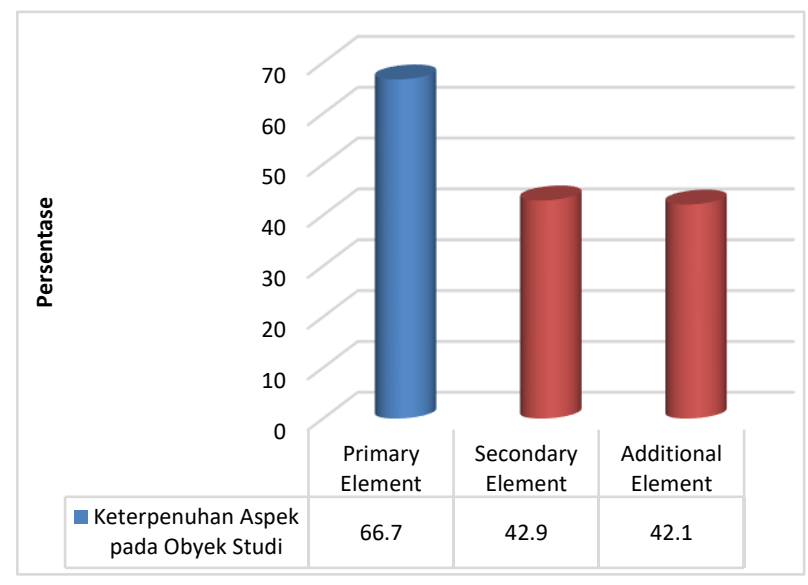

Gambar 10. Hasil Kesimpulan Kuisioner Standar Kampung Wisata Internasional pada Kampung Topeng

Dari penjabaran konsep genius loci pada masing-masing kampung sebelumnya, dapat disimpulkan bahwa kampung 3G merupakan kampung tematik yang berhasil menerapkan keempat parameter konsep Genius Loci. Sedangkan, Kampung Kampung Topeng mampu menerapkan 3 parameter, dan 
Kampung Warna Warni hanya mampu menerapkan 2 parameter.

Dari penilaian standar Kampung Wisata Internasional yang telah dipaparkan di atas, dapat disimpulkan bahwa Kampung $3 \mathrm{G}$ unggul dengan memenuhi 2 elemen standar kampung wisata internasional yaitu elemen primer dan elemen tambahan, sedangkan Kampung Topeng memenuhi 1 elemen yaitu elemen primer, dan yang paling terakhir adalah Kampung Warna Warni Jodipan yang hanya memenuhi 1 elemen saja dan bukan elemen utama yaitu elemen tambahan. Hal ini menunjukkan diantara ketiga kampung Kampung 3G telah dirancang secara komprehensif dan memiliki nilai sustainabilitas yang tinggi bagi warganya serta cukup potensial dalam pengembangannya sebagai destinasi wisata internasional sehingga apabila trend kampung tematik memudar, kampung $3 \mathrm{G}$ dapat tetap bertahan. Adapun rekomendasi desain dan pengembangan fasilitas yang harus dipenuhi oleh Kampung 3G adalah sebagai berikut:

a. Penambahan fasilitas penginapan dan pasar pada area kampung. Fasilitas penginapan pada Kampung 3G dapat mengguaakan beberapa rumah warga yang ada mengingat luas kampung yang tidak cukup besar.

b. Penguatan branding Kampung 3G melalui kegiatan yang dapat memberdayakan warga melalui hasil produk buatan warga yang dapat dijual sebagai produk khas dari Kampung 3G

\section{KESIMPULAN}

Untuk mengembangkan program kampung tematik, pemerintah, masyarakat dan akademisi harus mempertimbangkan faktorfaktor lain selain aspek visual antara lain kontrol fisik kampung terhadap lingkungan alam sekitarnya, fungsi ruang dan bangunan yang dirancang pada area kampung yang digunakan untuk mengakomodasi kegiatan warga dan wisatawan, struktur sosial warga serta simbol budaya yang tercipta dari keberadaan kampung tematik tersebut. Dari hasil penelitian ini dapat dilihat bahwa Kampug Tematik 3G yang dirancang dengan memprioritaskan kontrol fisik dalam merevitalisasi masalah lingkungan dan kondisi permukimannya mampu berkembang menjadi kampung tematik yang memiliki nilai berkelanjutan yang tinggi. Dalam pengembangan lebih lanjut, untuk menjadikan kampung tematik di Malang menjadi tujuan wisata internasional, maka sebuah kampung tematik harus memenuhi tiga aspek standar kampung wisata internasional. Kampung tematik $3 \mathrm{G}$ telah mampu memenuhi 2 dari 3 aspek standar kampung wisata internasional dibandingkan dengan dua kampung tematik lainnya. Hal ini menunjukkan bahwa kampung tematik yang dibangun dengan memperhatikan faktor lokalitas atau genius loci dapat bertahan walaupun trend kampung tematik nantinya akan memudar.

\section{REFERENSI}

Aeni, Yulia Lutfi Nur. 2017. Kontribusi Kampung Warna Jodipan Kota Malang dalam Meningkatkan Pemberdayaan Ekonomi dan Pendidikan Sosial Masyarakat Menuju Smart City. Skripsi. Malang: UIN Maulana Malik Ibrahim

Artiningrum, Primi et. al . 2017. Adaptasi Arsitektur Vernakuler Kampung Nelayan Bugis di Kamal Muara. Jakarta : Jurnal NALARs Volume 61/1: 69-84

Dewi, Puru Rahayu Sitha, Putra, Krena Aditya Ramadhan, Priautama, I Gde Banyu. Konsep Genius Loci Norberg-Schulz dalam Arsitektur. Bandung: ITB

Ph.D. Istoc, Elena Manuela. 2012. Urban Cultural Tourism And Sustainable Development. International Journal For Responsible Tourism Vol. 1 No.1

Norberg-Schulz, Christian. 1991. Genius Loci, Towards a Phenomenology of Architecture. Edinburgh: Edinburgh College of Art Library

Subadyo, A. Tutut. 2018. Pengembangan Dusun Baran, Tlogowaru, Kedungkandang Sebagai Kampung Wisata Topeng Di Kota Malang. Malang: Jurnal ABDIMAS Unmer Malang Vol. 3 No.1, Juni 2018, Hal:17 
Suryo, Bagus. 2017. Kembangkan Kampung

Tematik. Jakarta: Media Indonesia

Ujianto, Bayu Teguh, Zahro, Hani Sulfia dan Maringka, Breeze. Kegiatan Perancangan Kampung Belimbing Rw.08 - 09, Kel. Blimbing, Kec. Blimbing, Kota Malang. Malang: PAWON: Jurnal Arsitektur, Volume II Nomor 02, Juli - Desember 2018, ISSN 2597-7636

Utami, Ima Hidayati. 2018. Strategi Penguatan Kampung Glintung Go Green (3G) sebagai Destination Branding Obyek Wisata Edukasi Di Malang. Malang: Jurnal Administrasi dan Bisnis, Volume : 11, Nomor : 1, Juli 2017, ISSN 1978-726X

Winarni, Sri. 2011. Genius Loci Pada Permukiman Masyarakat Kudus Kulo (Kawasan Kota Lama Kudus). Malang: Universitas Brawijaya 